\title{
Analysis of Public Procurement of Medicines in Russia
}

\section{Análisis De La Contratación Pública De Medicamentos En Rusia}

\author{
Natalia Alekseevna PRODANOVA \\ Plekhanov Russian University of Economics, Moscow, Russian Federation \\ ORCID: orcid.org/0000-0001-5140-2702 \\ Elena Ivanovna ZATSARINNAYA \\ Plekhanov Russian University of Economics, Moscow, Russian Federation \\ ORCID: orcid.org/0000-0002-9400-4285

\section{Marina Alexandrovna MOTOVILOVA} \\ Plekhanov Russian University of Economics, Stremyanny lane, 36, Moscow, 117997, Russian \\ Federation \\ ORCID: orcid.org/0000-0002-1255-142X
}

\section{Irina Edwardovna GURYANOVA}

Financial University under the Government of the Russian Federation, Shcherbakovskaya Str, 38, Moscow, 105187, Russian Federation

\section{Elena G. PETRENKO}

Kuban state agrarian university named after I. T. Trubilin, Russian Federation ORCID: 0000-0002-7591-0768

\section{Nadezhda Konstantinovna GAVRILIEVA}

Yakut State Agricultural Academy, Yakutsk, Russian Federation

ORCID:0000-0002-8591-6880

Received 09-08-20 Revised 10-10-20

\section{* Correspondence}

Email: : prodanova-00@mail.ru
Accepted 12-12-20 On line 03-15-21

\section{Citation:}

Natalia Alekseevna Prodanova, Elena Ivanovna Zatsarinnaya,
Marina Alexandrovna Motovilova, Irina Edwardovna
GURYANOVA, Elena G. PETRENKO, Nadezhda Konstantinovna
GAVRILIEVA. (2021). Analysis of Public Procurement of
Medicines in Russia. Propósitos y Representaciones, 9 (SPE3),
e1141. Doi: http://dx.doi.org/10.20511/pyr2021.v9nSPE3.1141

Natalia Alekseevna Prodanova, Elena Ivanovna Zatsarinnaya, Marina Alexandrovna Motovilova, Irina Edwardovna e1141. Doi: http://dx.doi.org/10.20511/pyr2021.v9nSPE3.1141 


\begin{abstract}
One of the main components of the drug supply of the country's population with medicines is public procurement, which at the legislative level implements the principle of universal access to medical care and guarantees the quality of medical services provided. The authors analyzed the system of public procurement of medicines in Russia: the main sources of financing, customers and suppliers, territorial distribution, structure of methods of placing state orders are determined.
\end{abstract}

Keywords: medicines (preparations), healthcare system, public procurement system, procurement procedures, auction, lot, sources of financing

\title{
Resumen
}

Uno de los principales componentes de la oferta de medicamentos de la población del país es la contratación pública, que a nivel legislativo implementa el principio de acceso universal a la atención médica y garantiza la calidad de los servicios médicos brindados. Los autores analizaron el sistema de contratación pública de medicamentos en Rusia: se determinan las principales fuentes de financiación, clientes y proveedores, distribución territorial, estructura de los métodos de realización de pedidos estatales.

Palabras clave: medicamentos (preparados), sistema de salud, sistema de contratación pública, procedimientos de contratación, subasta, lote, fuentes de financiamiento

\section{Introduction}

The public procurement segment is one of the components of the pharmaceutical market in Russia, which is very predictable and stable. Financing of this type of procurement mainly comes from the funds of compulsory medical insurance (MHI). The main purpose of the contract system in the conclusion of public procurement is transparency and openness of the entire procedure for placing and executing a state contract, for which a single publicly accessible information system, a register of concluded contracts and unfair suppliers has been created. The process of preparation and implementation of state contracts is aimed at ensuring that it is impossible to carry out any actions that contradict the mandatory legislative norms of the Russian Federation, by participants in procurement activities, including the inability of planning and implementing actions that contradict legislative acts.

The system of drug supply of municipal health care institutions is regulated by Federal Law No.44 "On the contract system in the field of procurement of Goods, Works, and Services for state and municipal needs" and Federal Law No.223 "On procurement of Goods, Works, and Services by certain types of legal entities", which are the starting point for specific regulation of various relations related to drug supply issues.

The state supports domestic manufacturers by purchasing medicines, necessary equipment and medical products for institutions that are part of the healthcare system through state contracts, promoting competition and the development of innovative technologies. The role of the State in this area is increasing.

\section{Methods}

The methodological basis of the study is a set of measures of scientific knowledge, including dialectics, analysis, synthesis, induction, deduction, statistical method, comparative legal method, system approach. 


\section{Results}

In modern conditions, the pharmaceutical market in Russia is represented by two segments: commercial and state. The commercial market of pharmaceutical products is engaged in the sale of medicines through pharmacy chains, without taking into account sales carried out under the Program of Additional Drug provision. It should be noted that in 2019 there was an increase in the commercial market of medicines by $3.0 \%$, amounting to $1,021.1$ billion rubles. In total, the consumption of medicines in 2019 through the pharmacy network reached 5.1 billion rubles. packaging, which is $1.9 \%$ less than in 2018 .

The state market of pharmaceutical products is engaged in providing medicines through pharmacy chains not only under the Program of additional Drug provision, regional benefits, but also sells medicines through medical and preventive institutions.

Therefore, according to paragraph 1 of Article 4 of the Federal Law of 12.04.2010 No.61 "On circulation of Medicinal Products", pharmaceutical substances and medical preparations are considered to be medicinal products. Only pharmaceutical products that are registered in the state register are recognized as medicines that are allowed for use in the treatment of patients.

Medical institutions can purchase medicines from both manufacturers and wholesale organizations of medicines or pharmacies. Also, medical institutions have the right to receive medicines for supply centrally.

Medicines sold wholesale should be included in the state register. The seller of medicines, as a wholesale seller, must have a license for pharmaceutical activities (with the indication "wholesale of pharmaceutical products"). In addition, the wholesale sale of medical products must comply with the Rules of Good Distribution Practice within the framework of the Eurasian Economic Union, approved by the decision of the Council of the Eurasian Economic Commission No. 80 of 03.11 .2016 .

Medicines are one of the most problematic purchases under Federal Law No.44 and Federal Law No.223. The share of purchases under Federal Law No.44 in 2019 is 86\%, while Federal Law No.223 accounts for $14 \%$.

Table 1. Completed auctions

\begin{tabular}{|c|c|c|c|c|}
\hline \multirow{2}{*}{ Year } & \multicolumn{2}{|c|}{ Federal Law No.223 } & \multicolumn{2}{c|}{ Federal Law No.44 } \\
\cline { 2 - 5 } & billion RUB & $\%$ & billion RUB & $\%$ \\
\hline 2015 & 53,2 & $14,3 \%$ & 0,2 & $0,3 \%$ \\
\hline 2016 & 156,7 & $30,6 \%$ & 0,5 & $1,6 \%$ \\
\hline 2017 & 61,2 & $14,2 \%$ & 19,4 & $4,5 \%$ \\
\hline 2018 & 81,5 & $16,8 \%$ & 26,2 & $5,4 \%$ \\
\hline 2019 & 84,9 & $14 \%$ & 515, & $86 \%$ \\
\hline
\end{tabular}

In 2019, more than 481 thousand orders for the purchase of medicines were published for the needs of medical institutions, which is $17 \%$ higher than in 2018. The number of cancelled tenders increased from 75 to 121 thousand auctions (by 60\%), the number of completed auctions by $1 \%$. The share of completed auctions was $70 \%$ of the total number of bids, which is significantly less than in 2018 (81\%). The share of canceled applications in 2019 increased from $18 \%$ to $25 \%$. In general, the number of completed tenders has not changed significantly over the past 5 years.

The main method of placing orders under Federal Law No.44 in 2019 is an electronic open auction with a share of $92 \%$, while under Federal Law No.223 the most frequently used method is to request quotations (40\%) and purchase from a single supplier (34\%). The share of auctions 
remaining at the stages of placement "commission work" remains quite high, which is associated with failed tenders.

Table 2. Stages of placing an order

\begin{tabular}{|c|c|c|c|c|c|}
\hline $\begin{array}{c}\text { Stage of placing } \\
\text { an order }\end{array}$ & 2015 & 2016 & 2017 & 2018 & 2019 \\
\hline $\begin{array}{c}\text { Work of the commission, } \\
\text { submission of } \\
\text { applications }\end{array}$ & 582 & 323 & 250 & 3676 & 22447 \\
\hline Placement completed & 288037 & 324061 & 320325 & 334061 & 338406 \\
\hline Placement canceled & 49698 & 54220 & 43920 & 75334 & 120656 \\
\hline Total auctions & 338317 & 378604 & 364395 & 413071 & 481509 \\
\hline
\end{tabular}

In monetary terms, the share of cancelled tenders in 2019 increased significantly compared to 2018. This is due to the fact that most of the tenders cancelled in April-June 2019 were re-drawn from August to September. For 63.5 thousand published schedule plans with the sum of 51.3 billion rubles - it was not possible to place an order, but for 5.6 thousand of them - more than one order placement was carried out.

Despite a small difference in the number of completed auctions (1\%) in 2019, the total amount of purchases of medicines increased by $20 \%$ and amounted to 578 billion rubles on the winner's prices.

In 2019, according to the completed auctions for the purchase of medicines, the difference between the sum of the winners ' prices ( 578 billion rubles) and the sum of the initial maximum prices declared in the documentation (601 billion rubles) was $3.3 \%$.

Table 3. Volumes of completed auctions

\begin{tabular}{|c|c|c|c|c|c|}
\hline \multirow{2}{*}{ Year } & \multirow{2}{*}{$\begin{array}{c}\text { Total } \\
\text { auctions }\end{array}$} & $\begin{array}{c}\text { The volume of } \\
\text { auctions, the } \\
\text { price of the } \\
\text { order, } \\
\text { billion RUB }\end{array}$ & $\begin{array}{c}\text { The volume of } \\
\text { auctions, the price } \\
\text { of the winner, } \\
\text { billion RUB }\end{array}$ & $\begin{array}{c}\text { Saving, } \\
\%\end{array}$ & $\begin{array}{c}\text { Increase in the } \\
\text { volume of played } \\
\text { trades } \\
\text { (to the previous } \\
\text { year), \% }\end{array}$ \\
\hline 2015 & 338316 & 373,0 & 342,3 & $-8,2$ & - \\
\hline 2016 & 378605 & 511,6 & 466,4 & $-8,8$ & $+26,6$ \\
\hline 2017 & 364394 & 431,3 & 384,5 & $-10,9$ & $-21,3$ \\
\hline 2018 & 413072 & 488,5 & 457,8 & $-6,3$ & $+16,1$ \\
\hline 2019 & 481509 & 600,8 & 578,3 & $-3,7$ & $+20,9$ \\
\hline
\end{tabular}

A sharp increase in the volume of drawn trades in 2016 compared to 2015 is due to the fact that there was a procedural change in trading conducted under the law Federal Law No.223, which began on January 1, 2017. In this regard, those customers who previously worked under Federal Law No.223, until the beginning of 2017, required to either publish or draw the largest number of auctions. In 2017, the expectations of bidders were not met and the previous trend of annual growth remained.

In 2019, the total amount of purchases of medicines increased significantly and amounted to $20.9 \%$, reaching 578.3 billion rubles. Moreover, the difference between the sum of the winners ' prices and the sum of the initial maximum prices was $3.7 \%$.

According to the type of lot, most of the tenders belong to the category of "Monolot", i.e. a lot containing a single international non-proprietary name. In recent years, there has been a clear trend towards a gradual increase in the share of "Monolots". At the same time, since 2013, the structure of lots is gradually and steadily changing towards single-position lots. In 2012, the share 
of multi-item lots prevailed, i.e. lots that contain several dosage variations for one international nonproprietary name or several international nonproprietary names. In 2013, single-position pillboxes are played in less than half of the cases, and since 2014, the share of single-position lots increases every year and accounts for more than half of all lots.

Table 4. The type and structure of lots

\begin{tabular}{|c|c|c|c|c|c|}
\hline The lot type & $\mathbf{2 0 1 5}$ & $\mathbf{2 0 1 6}$ & $\mathbf{2 0 1 7}$ & $\mathbf{2 0 1 8}$ & $\mathbf{2 0 1 9}$ \\
\hline Monolot & $66,0 \%$ & $69,1 \%$ & $73,2 \%$ & $74,2 \%$ & $74,9 \%$ \\
\hline Mixed lot & $34,0 \%$ & $30,9 \%$ & $26,8 \%$ & $25,8 \%$ & $25,1 \%$ \\
\hline The structure of the lot & & & & & \\
\hline Single-position & $53,8 \%$ & $57,0 \%$ & $61,6 \%$ & $64,0 \%$ & $65,3 \%$ \\
\hline Multi-position & $46,2 \%$ & $43,0 \%$ & $38,4 \%$ & $36,0 \%$ & $34,7 \%$ \\
\hline Total lots & 288037 & 324061 & 320225 & 334061 & 338406 \\
\hline
\end{tabular}

If we talk about the method of placing an order on the tender market, we can distinguish such as: open auction, request for quotations and purchase from a single supplier. The most commonly used method of public procurement is an electronic open auction. It accounted for: in $2015-85.6 \%$, in $2016-71.9 \%$, in $2017-77.3 \%$, in 2018 and $2019-76 \%$ and $83.2 \%$, respectively, of the total volume of public procurement. In 2016, only $72 \%$ of the total volume of orders were placed through an electronic open auction in monetary terms, which is due to a significant increase in the request for quotations as a form of bidding under Federal Law No.223 (minimum value), and in 2019, open auctions as a form of procurement increased to $83 \%$. Purchases from a single supplier over the past five years have been fairly stable and account for $10 \%$.

Table 4. Methods of placing orders

\begin{tabular}{|c|c|c|c|c|c|}
\hline \multirow{2}{*}{ Methods of placing orders } & \multicolumn{5}{|c|}{ Year } \\
\cline { 2 - 6 } & $\begin{array}{c}2015 \\
\text { billions } \\
\text { RUB }\end{array}$ & $\begin{array}{c}2016 \\
\text { billions } \\
\text { RUB }\end{array}$ & $\begin{array}{c}2017 \\
\text { billions } \\
\text { RUB }\end{array}$ & $\begin{array}{c}2018 \\
\text { billions } \\
\text { RUB }\end{array}$ & $\begin{array}{c}2019 \\
\text { billions } \\
\text { RUB }\end{array}$ \\
\hline Open auction in electronic form & 318,2 & 359,8 & 333,0 & 371,3 & 499,3 \\
\hline Purchasing from a single supplier & 16,8 & 40,1 & 41,8 & 49,1 & 61,1 \\
\hline Request for quotations, offers & 36,4 & 92,3 & 27,0 & 45,1 & 38,2 \\
\hline Special investment contract & - & - & 28,9 & 22,6 & 1,7 \\
\hline Other & - & 7,9 & - & - & - \\
\hline
\end{tabular}

The share of purchases under Federal Law No.44 has been stable at $85-86 \%$ over the past years, while the share of purchases under Federal Law No.223 is 14-15\%. According to Federal Law No.44, the main method of placing orders is an open auction in electronic form - 92\%, while other methods are more often used under Federal Law No.223: request for quotations - 40\% and purchase from a single supplier-34\%.

From 2013 to 2018, purchasing activity within the framework of the " National Immunisation Schedule" is gradually increasing. The volume of purchases under the vaccine prevention program during this period increased more than fourfold: from 4.5 billion rubles in 2013 to 22 billion rubles in 2019, despite the fact that in 2018 there was a slight decrease in volumes to 13.3 billion rubles in prices of the winners.

Table 5. Procurement category for completed auctions

\begin{tabular}{|c|c|c|c|c|c|}
\hline Purchase category & 2015 & 2016 & 2017 & 2018 & 2019 \\
\hline Hospital purchases & 111,6 & 119,7 & 126,7 & 149,7 & 218,8 \\
\hline Preferential purchases & 118,2 & 138,8 & 148,4 & 185,4 & 207,9 \\
\hline Federal program "7(12) & 43,4 & 39,1 & 45,9 & 62,0 & 84,1 \\
\hline
\end{tabular}




\begin{tabular}{|c|c|c|c|c|c|}
\hline nosologies" & & & & & \\
\hline $\begin{array}{c}\text { Federal target program } \\
\text { vaccinal prevention " }\end{array}$ & 8,1 & 10,3 & 15,1 & 13,3 & 21,8 \\
\hline $\begin{array}{c}\text { Federal target program " } \\
\text { Hepatitis B, C/HIV» }\end{array}$ & - & - & 24,7 & 24,3 & 26,4 \\
\hline Other & 61,0 & 158,5 & 23,7 & 23,0 & 19,5 \\
\hline
\end{tabular}

According to the results of 2019, we can talk about an increase in purchases of medicines under the Federal Program "7/12 nosologies" (at the end of 2018, 12 nosologies were included in this program). Public procurement under this program in 2017 amounted to $44-46$ billion rubles after a decrease in 2016; in 2018 the financing of the program increased, which affected an increase of 35\%, reaching 62 billion rubles. This trend continued in 2019, reaching 84 billion rubles with an increase of $36 \%$.

In 2017, purchases of antiretroviral drugs "Federal Target Program Hepatitis B, C/HIV" were allocated to a separate category; in 2019, the volume of purchases remained approximately at the level of 2017-2018 (26 billion rubles).

In 2019, the clinical segment and the segment working with preferential medicines showed positive growth in market volumes. Clinical purchases increased by $46 \%$, and purchases of concessional medicines - by $12 \%$. The increase in the clinical segment can be explained by the fact that part of the purchases of cancer drugs was transferred to the medical and preventive institutions themselves, with their subsequent financing from the Federal Compulsory Health Insurance Fund under certain conditions.

The source of funding for these types of orders for the period from 2016 to 2019 is the "Federal Budget", with an increase in funding by $11 \%$ from 141 billion rubles in 2018 to 157 billion rubles in 2019 .

Table 6. Sources of funding

\begin{tabular}{|c|c|c|c|c|c|c|c|c|c|c|}
\hline \multirow[t]{3}{*}{$\begin{array}{c}\text { Sources of } \\
\text { funding }\end{array}$} & \multicolumn{10}{|c|}{$\begin{array}{l}\text { Sources of funding, } \\
\text { the price of the winner }\end{array}$} \\
\hline & \multicolumn{2}{|c|}{2015} & \multicolumn{2}{|c|}{2016} & \multicolumn{2}{|c|}{2017} & \multicolumn{2}{|c|}{2018} & \multicolumn{2}{|c|}{2019} \\
\hline & $\begin{array}{l}\text { billion } \\
\text { RUB }\end{array}$ & $\%$ & $\begin{array}{l}\text { billion } \\
\text { RUB }\end{array}$ & $\%$ & $\begin{array}{l}\text { billion } \\
\text { RUB }\end{array}$ & $\%$ & $\begin{array}{l}\text { billion } \\
\text { RUB }\end{array}$ & $\%$ & $\begin{array}{l}\text { billion } \\
\text { RUB }\end{array}$ & $\%$ \\
\hline $\begin{array}{c}\text { The Federal } \\
\text { budget }\end{array}$ & 92,6 & 32,6 & 84,4 & 24,8 & 128,1 & 36,4 & 140,9 & 31 & 156,8 & 27 \\
\hline $\begin{array}{c}\text { The regional } \\
\text { budget }\end{array}$ & 64,7 & 22,8 & 68,5 & 20,2 & 89,9 & 25,5 & 94,7 & 21 & 146,3 & 25 \\
\hline $\begin{array}{c}\text { The Federal } \\
\text { Compulsory } \\
\text { Medical } \\
\text { Insurance Fund }\end{array}$ & 43,8 & 15,4 & 48,1 & 14,2 & 43,9 & 12,5 & 54,29 & 12 & 81,3 & 14 \\
\hline $\begin{array}{c}\text { Funds of the } \\
\text { budget institution }\end{array}$ & 39,4 & 13,9 & 68,5 & 20,2 & 51,6 & 14,6 & 68,2 & 15 & 86,0 & 15 \\
\hline Municipal budget & 17,0 & 6 & 42,6 & 12,5 & 17,2 & 4,9 & 18,5 & 4 & 2,9 & -1 \\
\hline $\begin{array}{l}\text { Inter-budget } \\
\text { transfers }\end{array}$ & 15,9 & 5,6 & 14,7 & 4,3 & 11,4 & 3,2 & 12,6 & 3 & 15,3 & 3 \\
\hline $\begin{array}{l}\text { Extra-budgetary } \\
\text { sources of } \\
\text { funding }\end{array}$ & 10,5 & 3,7 & 12,9 & 3,8 & 10,2 & 2,9 & 9,6 & 2 & 10,2 & 2 \\
\hline $\begin{array}{l}\text { No other source } \\
\text { of funding is } \\
\text { specified }\end{array}$ & - & - & - & - & - & & 57,6 & 12 & 80,5 & 14 \\
\hline
\end{tabular}


The number of purchases and their volume at the expense of the regional budget and the Federal Compulsory Medical Insurance Fund (FFOMS) increased significantly - by 54\% from both sources. Also, these channels have increased their share in the total distribution of funds $25 \%$ in the regional budget, in 2018 this figure was $21 \%$, and $14 \%$ in FFOMS against $10.5 \%$ in 2018. The share of municipal budgeting in 2019 decreased and showed a negative trend of $-1 \%$ compared to the indicators of 2018.

If we consider financing by federal districts, the largest part of state financing takes place in the Central Federal District with an indicator of $48 \%$ of the total volume of orders. This is due to the fact that funding for federal programs of preferential provision of medical products and central military hospitals is located in the Central Federal District, including Moscow and the Moscow Region.

At the same time, regional funding from the respective budgets is most actively carried out in the North-Western Federal District with a share of 39\%, the Far Eastern and Ural Federal Districts with a share of $36 \%$ in each, the smallest share of regional funding from the regional budget falls on the Volga District with a share of $21 \%$. This situation in the Volga region is associated with the main purchases of medicines in Nizhny Novgorod, carried out through the regional pharmacy with a share of 38\%. A similar situation is observed in other regions, such as Tatarstan and the Krasnoyarsk Territory. Funding from the Federal Compulsory Medical Insurance Fund (FFOMS) is carried out in the Southern Federal District with a share of 36\% and in the North Caucasus Federal District with a share of 35\% and in the Far East with 33\%, respectively. It should be noted that other sources of financing are practically not used in the North Caucasus Federal District and they account for only 3\%. The same situation is observed in the Siberian Federal District with a $3 \%$ share of other financing.

From 2016 to 2019, more than 11 thousand different customers participated in tendering for the supply of medicines, in 2019 there were slightly more than 8.5 thousand customers. Collectively, the 50 largest customers accumulate 60\% (337 billion rubles) of the total budget supply of medicines in Russia.

Table 7. Top 10 customers in 2019

\begin{tabular}{|l|c|c|}
\hline No. & Customers & $\begin{array}{c}\text { The price of the } \\
\text { winner, billion } \\
\text { RUB }\end{array}$ \\
\hline 1. & Ministry of Health of the Russian Federation & 138,9 \\
\hline 2. & $\begin{array}{c}\text { State Institution of the City of Moscow "Procurement Agency } \\
\text { (Contract Service) of the Moscow Department of Health" }\end{array}$ & 47,2 \\
\hline 3. & National Immunobiological Company "Nacimbio" JSC & 23,1 \\
\hline 4. & Ministry of Health of the Moscow Region & 16,8 \\
\hline 5. & State enterprise of Nizhny Novgorod Regional pharmacy & 8,6 \\
\hline 6. & Health Committee of St. Petersburg & 6,4 \\
\hline 7. & $\begin{array}{c}\text { State Unitary Enterprise } \\
\text { "Medical technology and pharmacy of Tatarstan" }\end{array}$ \\
\hline 8. & Ministry of Health of the Sverdlovsk Region & 3,5 \\
\hline 9. & $\begin{array}{c}\text { State Budgetary Healthcare Institution (Moscow State } \\
\text { Oncological Hospital No. 62) }\end{array}$ & 3,4 \\
\hline 10. & $\begin{array}{c}\text { State Budgetary Healthcare Institution "Saint-Petersburg clinical } \\
\text { scientific and practical center for specialized types of medical } \\
\text { care (oncological)" }\end{array}$ & 3,3 \\
\hline
\end{tabular}

The first place in this rating is occupied by the Ministry of Health of the Russian Federation, which accounted for almost $25 \%$ of the total volume of purchases of medicines in 2019. For the first time in recent years, the TOP customers included medical and preventive 
institutions, the leading positions are occupied by cancer centers in Moscow and St. Petersburg with purchases of 3 billion rubles.

Summing up the results of the analysis, it can be stated that in 2017 there was a decrease in the volume of auctions held compared to 2016. This decrease was caused by a large number of tenders drawn at the end of 2016 in anticipation of changes in the rules of bidding from January 1, 2017, which immediately affected a sharp increase in all market indicators in 2016 compared to 2015. In 2017, the situation stabilized, so in comparison with 2016, we can observe a decrease in the main volumes and the number of participants, including distribution companies.

In 2018, the situation began to stabilize and a slight increase in total purchases began. In 2019 , the volume of procurement of medicines increased due to additional funding of federal programs and the launch of the project "Fight against cancer". We can note the growth of $23 \%$, especially in the segment of the budget market-the Federal Program of 7(12) nosologies by 36\%, "preferential purchases" by $12 \%$ and the clinical sector by $46 \%$, with stabilization in other market segments. The increase in funding is mainly due to the purchase of antitumor drugs (ATC group $\mathrm{L}$ ), as well as the purchase of systemic antimicrobial agents (ATC group J).

The unfolding of the program to combat cancer diseases also affected the picture by other criteria, namely, that the rating of customers included the medical and preventive institutions themselves, mainly republican and regional cancer dispensaries, and the leaders of the former cancer centers of Moscow and St. Petersburg: State Budgetary Healthcare Institution (Moscow State Oncological Hospital No. 62) and State Budgetary Healthcare Institution "Saint-Petersburg clinical scientific and practical center for specialized types of medical care (oncological)". In addition, in 2019, several expensive original antitumor drugs were allowed to enter the Russian market, which immediately affected the increase in the total amount of purchases.

If we talk about the specifics of budgeting in 2019, the main factor here is the cancellation of a significant number of auctions in the first half of the year. By the end of 2019, the situation has leveled off a little, but the situation is not fundamentally changing. It was affected by the fact that most of the suppliers of medicines refused to go to auctions with a low initial maximum purchase price. First of all, this was negatively affected by the introduction of a new payment scheme from 01.2019. In the country of canceled applications, the share of all received applications was more than $25 \%$, with higher rates for individual medicines.

About $10 \%$ of the published schedule plans failed to be drawn in 2019, despite the fact that some of these auctions were announced repeatedly.

This situation with the cancellation of auctions inevitably affected the supply of medicines with interruptions, which was further aggravated by the introduction of mandatory labeling in 2020. All the leading suppliers remained in their places, but in general the situation is very, very unstable. The top line of the rating is continuously headed by JSC Pharmstandard and JSC RPharm.

In 2019, the trend of the last five years continued in the budget market of medicines. Due to national programs, the market volumes are growing, the main participants of this market are in their places, the situation does not change fundamentally.

\section{Conclusions}

The health care system has recently faced more and more new challenges, both of a global nature and of a specific and systemic nature. Global challenges and problems are not only the emergence of new diseases and viruses, including COVID-19, but also the ongoing changes in the structure of the population's morbidity, pushing for the creation of more and more new drugs with an increasing demand for medicines and medical services. Public procurement is a stable and predictable segment of the pharmaceutical market in Russia, and the system of public procurement of medicines is a system-forming component of the drug supply of the population, which 
implements legally established guarantees of the availability and quality of medical care. Further development of the procurement system acts as a locomotive for improving the efficiency of public funds management, which is one of the conditions for the growth of socio-economic development of the Russian Federation.

\section{References}

Fedyaev, D. V., Fedyaeva V. K., Omelyanovsky V. V. (2014). Analysis of the state of the market of public procurement of drugs used in the treatment of rare diseases. Pharmacoeconomics. Modern pharmacoeconomics and pharmacoepidemiology, 17.

Malaev, M.G. (2014). Analysis of procurement of medicines after the entry into force of the law on the federal contract system. High-quality clinical practice, 2, 77-82.

Omelyanovsky, V. V., Sura, M. V., Gerasimova, K. V., Arsentieva, M. V., Tatarinov, A. P. (2014). Assessment of the necessary financial costs for drug provision for patients with rare diseases in the Russian Federation. Newsletter. Expert Council on Healthcare of the Federation Council Committee on Social Policy of the Federal Assembly of the Russian Federation.

Review of the supply of medicinal products in the public sector of the pharmaceutical market of the Russian Federation by the end of 2018 - https://alpharm.ru/ru/analytics/obzorpostavok-lp-v-gosudarstvennom-segmentes-farmacevticheskogo-rynska-rf-po-itogams2018-g

Sokolova, S. V., Orlov, A. S., Rumyantsev M. S. (2013). Pharmaceutical market: public procurement of medicines. - M., problems of modern Economics, N 4 (48).

Ukraintsev, V., \& Ahohov, A. (2018). Logistics in medicine: the analysis and place smart contracts in public procurement. Logistics", 6.

Zemtsova, N. V., \& Kopoteva, E. A. (2020). State procurement of medicines: analysis of the state and problems of improvement Socio-economic management: theory and practice, 1(40), 27-29. 